\title{
HUBUNGAN PENDIDIKAN DAN HUKUM DALAM MENSEJAHTERAKAN MANUSIA
}

\author{
Abdul Kallang \\ Sekolah Tinggi Agama Islam Negeri Watampone, Bone, Indonesia \\ e-mail: abdul_kallang@gmail.com
}

\begin{abstract}
Abstrak
This paper discusses the relationship between education and law in the welfare of humans. So, the discussion is related to the educational situation that should be applied as well as the law that is appropriately enforced, not only many rules, but the rules are not enforced. All teachers must understand and understand that the concept or method of education is very different now. The point is we must understand, practice with the present context. Likewise, the law must be applied in the context of the present. In everyday life, humans must walk, not stop, turn to the left and to the right, sometimes backward, but must continue to advance in achieving what he wants by paying attention to the situation around one of them is to pay attention to those related to education and law. Both epistemologically, axiologically and ontologically. what I mean here is what is the definition of education and also law? What is the basis of the importance of education and law? And c. What is the relationship between education and law in the welfare of humans.
\end{abstract}

Keyword: Education, Law, Welfare.

\section{Pendahuluan}

Dalam kehidupan, manusia sebagai mahluk sosial yang hidup besama-sama dan berdasarkan moral estetika, etis dan dianamis sangat bergantung pada pendidikan dan juga hukum. Pasalnya pendidikan dan hukum sangat berpengaru besar bagi keberlangsungan hidup mereka dan juga kesejahteraan manusia itu sendiri.

Kendati pendidikan kadang diremehkan untuk penegembangan dan kesadaran akan pentingnya, namun tidak bisa di tampik lagi jika pendidikan memang harus ada pada setiap pribadi manusia baik dewasa atau belum dewasa. Semua agama menganjurkan akan perlunya pendidikan, islam melalui Al-qur'an memberi apresiasi terhadap orang yang berilmu "Allah mengangkat derajat orang yang beriman dan berilmu". Dari sisni betapa pentingnya pendidikan dalam kehidupan manusia itu sendidri. Namun pendidikan jika tidak di dukung oleh hukum yang mengaturnyasepertinya pendidikanpun akan barangsur sirna dan sulit untuk di kembangkan. Ini pentingnya untuk menulis hubungan natara keduanya.1

Selanjutnya menurut UU No. 20 Tahun 2003 tentang System Pendidikan Nasional, pendidikan adalah usaha sadar dan terencana untuk mewujudkan suasana belajar dan proses pembelajaran agar peserta didik secara aktif mengembangkan potensi dirinya untuk memiliki kekuatan spiritual keagamaan, pengendalian dirinya, keperibadian, kecerdasan, akhlak mulia, serta keterampilan yang diperlukan dirinya, masyarakat bangsa dan negara. 2

Dengan demikian dapat dimaknai bahwa pendidikan adalah proses sepanjang hayat dan perwujudan pembentukan diri secara utuh dalam pengembangan segenap potensi dalam rangka pemenuhan semua komitmen manusia sebagai individu, makhluk sosial dan sebagai makhluk Tuhan.3

Mendidik diartikan sebagai memberi nasihat, petunjuk, mendorong agar rajin belajar, memberi motivasi, menjelaskan sesuatu atau ceramah, melarang prilaku yang tidak baik, menganjurkan dan menguatkan perilaku yang baik, dan menilai apa yang telah

\footnotetext{
1. Kansil. Pengantar Ilmu Hukum dan Tata Hukum Indonesia. Jakarta, Balai Pustaka,h. 56

2. Kansil. Pengantar Ilmu Hukum dan Tata Hukum Indonesia

3 Lampiran UU No. 20 Tahun 2003 Tentang SISDIKNAS
} 
dipelajari anak, itu bisa dilakukan oleh semua orang.4 Dan tidak perlu susah-susah membuat pendidik menjadi profesional. Namun mendidik seperti ini tidak dapat menjamin anak-anak akan berkembang sempurna secara batiniah dan lahiriah.5

\section{Penegrtian pendidikan dan hukum.}

Pendidikan menurut UU No. 20 Tahun 2003 Tentang SISDIKNAS Pendidikan adalah usaha sadar dan terencana untuk mewujudkan suasana belajar dan proses pembelajaran agar peserta didik secara aktif mengembangkan potensi dirinya untuk memiliki kekuatan spiritual keagamaan, pengendalian diri, kepribadian, kecerdasan, akhlak mulia, serta keterampilan yang diperlukan dirinya, masyarakat, bangsa dan Negara.6

Berdasarkan definisi di atas, 3 (tiga) pokok pikiran utama yang terkandung di dalamnya, yaitu: (1) usaha sadar dan terencana; (2) mewujudkan suasana belajar dan proses pembelajaran agar peserta didik aktif mengembangkan potensi dirinya; dan (3) memiliki kekuatan spiritual keagamaan, pengendalian diri, kepribadian, kecerdasan, akhlak mulia, serta keterampilan yang diperlukan dirinya, masyarakat, bangsa dan negara. Di bawah ini akan dipaparkan secara singkat ketiga pokok pikiran tersebut.

1. Usaha sadar dan terencana.

Pendidikan sebagai usaha sadar dan terencana menunjukkan bahwa pendidikan adalah sebuah proses yang disengaja dan dipikirkan secara matang (proses kerja intelektual). Oleh karena itu, di setiap level manapun, kegiatan pendidikan harus disadari dan direncanakan, baik dalam tataran nasional (makroskopik), regional/provinsi dan kabupaten kota (messoskopik), institusional/sekolah (mikroskopik) maupun operasional (proses pembelajaran oleh guru)7.

Berkenaan dengan pembelajaran (pendidikan dalam arti terbatas), pada dasarnya setiap kegiatan pembelajaran pun harus direncanakan terlebih dahulu sebagaimana diisyaratkan dalam Permendiknas RI No. 41 Tahun 2007. Menurut Permediknas ini bahwa perencanaan proses pembelajaran meliputi penyusunan silabus dan rencana pelaksanaan pembelajaran (RPP) yang memuat identitas mata pelajaran, standar kompetensi (SK), kompetensi dasar (KD), indikator pencapaian kompetensi, tujuan pembelajaran, materi ajar, alokasi waktu, metode pembelajaran, kegiatan pembelajaran, penilaian hasil belajar, dan sumber belajar.

2. Mewujudkan suasana belajar.

Pada pokok pikiran yang kedua ini terlihat adanya pengerucutan istilah pendidikan menjadi pembelajaran. Jika dilihat secara sepintas mungkin seolah-olah pendidikan lebih dimaknai dalam setting pendidikan formal semata (persekolahan). Terlepas dari benar-tidaknya pengerucutan makna ini, pada pokok pikiran kedua ini, bisa menangkap pesan bahwa pendidikan yang dikehendaki adalah pendidikan yang bercorak pengembangan (developmental) dan humanis, yaitu berusaha mengembangkan segenap potensi didik, bukan bercorak pembentukan yang bergaya behavioristik8

3. Memiliki kekuatan spiritual keagamaan.

Pokok pikiran yang ketiga ini, selain merupakan bagian dari definisi pendidikan sekaligus menggambarkan pula tujuan pendidikan nasional kita, yang menurut hemat saya sudah demikian lengkap. Di sana tertera tujuan yangberdimensi ke-Tuhan-an, pribadi, dan sosial. Artinya, pendidikan yang dikehendaki bukanlah pendidikan sekuler, bukan pendidikan individualistik, dan bukan pula pendidikan sosialistik, tetapi pendidikan yang mencari keseimbangan diantara ketiga dimensi tersebut.

Mendidik adalah membuatkan kesempatan dan menciptakan situasi yang kondusif agar anak-anak sebagai subjek berkembang sendiri. Mendidik adalah suatu upaya membuat anak-anak mau dan dapat belajar atas dorongan diri sendiri untuk

4. Pidarta, Made, Landasan Kependidikan. Jakarta, Rineka Cipta: 2000, h. 21

5 Lampiran UU No. 20 Tahun 2003 Tentang SISDIKNAS

6 Pidarta, Made, Landasan Kependidikan

7Lampiran UU No. 20 Tahun 2003 Tentang SISDIKNAS

8 Siswoyo, Dwi, dkk.. Ilmu Pendidikan, Yogyakarta UNY Press. 2007 
mengembangkan bakat, pribadi, dan potensi-potensi lainnya secara optimal. Berarti mendidik memusatkan diri pada upaya pengembangan afeksi anak-anak, sesudah itu barulah pada pengembangan kognisi dan keterampilannya.

Kompetensi lain yang perlu diperkenalkan kepada calon guru untuk dipelajari, dipahami, dilatih, dan dilaksanakan setelah bertugas di lapangan adalah sejumlah perilaku pendidik dalam proses pendidikan yang bisa dipilih salah satu atau beberapa diantaranya yang cocok dengan tujuan pendidikan setiap kali tatap muka. Perilaku-perilaku pendidik yang dimaksud adalah:

1. Pendidik bertindak sebagai mitra atau saudara tua peserta didik.

2. Melaksanakan disiplin yang permisif, ialah memberi kebebasan bertindak asal semua peserta didik aktif belajar.

3. Member kebebasan kepada semua peserta didik untuk mengaktualisasi potensi mereka masing-masing.

4. Mengembangkan cita-cita riil para peserta didik atas dasar pemahaman mereka tentang diri sendiri.

5. Melayani pengembangan bakat setiap peserta didik.

6. Melakukan dialog atau bertukar pikiran secara kritis dengan peserta didik.

7. Menghargai agama dalam dunia modern yang penuh dengan rasionalitas. Hal-hal di luar rasio manusia dibahas lewat agama.

8. Melakukan dialektika nilai budaya lama dengan nilai-nilai budaya modern.

9. Mempelajari dan ikut memecahkan masalah masyarakat, yang mencakup ekonomi, sosial, budaya, dan geografis, termasuk aplikasi filsafat pancasila.

10. Mengantisipasi perubahan lingkungan dan masyarakat pendidik atau bekerja sama dengan para peserta didik.

11. Member kesempatan kepada para peserta didik untuk berkreasi.

12. Mempergunakan metode penemuan.

13. Mempergunakan metode pemecahan masalah.

14. Mempergunakan metode pembuktian.

15. Melaksanakan metode eksperimentasi.

16. Melaksanakan metode berproduksi barang-barang nyata yang mungkin bisa dipasarkan.

17. Memperhatikan dan membina perilaku nyata agar positif pada setiap peserta didik. 9

Dimata islam pendidikan menjadi hal yang wajib, dimana manusia harus mempunyai pendidikan, akan tapi yang dimaksud pendidikan dalam agama islam bukan hanya apada pendidikan formal saja. Lebih luas dari itu islam mewajibkan pengikutnya agar untuk belajar atau mencari ilmu dimana kapan saja. Hal ini menandalan pentingnya suatu pendidikan bagi manusia sendiri. Hadist nabi mengatakan

Artinya:

$$
\text { العلم من اللد الي الهدياطلبو 10 - ما }
$$

Tuntutlah ilmu dari kalian lahir sampai kalian mati.

Dalam Al-Qur'an Allah memberi apresiasi kepada orang yang mepunyai ilmu.

Terjemahnya:

$$
\text { يرفع الذين امنوا و الذين اتول العلم الدرجة .....الاية }
$$

Allah akan engangkat derajat orang-oarang yang beriman dan berilmu.11

Dalam UU No. 20 Tahun 2003 Tentang Sisdiknas pendidikan, pendidikan adalah merupakan hal yang sangat penting, sehingga dalam penyelenggaraan pendidikan formal 
seluru anak bangsa diwajibkan mengenyam pendidikan paling rendah tingkat SMP, hal ini di dorong oleh pengadaan Dana BOS yang berfungsi mengurangi jumlah anak abngsa yang tidak sekolah karena alesan miskin.

Sedangkan dasar adanya hukum harus ada adalah sejara keberadaban manusia itu sendiri pasalnya terbentuknya hukum adalah sebab adanhya manusia. Kehidupan manusia menciptakan hukum. Dimana hukum itu biasanya berupa norma baik tertulis atau tidak tertulis. 12

Dalam islam seluruh hukum bersumber dari Al-Qur'an dan Al-hadist. Kedunya adalah sumberhukum yang tidak tergantikan walau zaman sudah berekambang. Pada dasaranya Al-hadist adalah penerang dari hukum yang terdapat pada Al-Qur'an. Maka terbentuknya hukum islam adalah sejak adanya atau turunya Al-Qur'an, walau pun wacana tentang adanya hukum itu sejak adanya manusia, namun melihat perkembangan hukum islam itu sendiri, islam mengalami reproduksi hukum mulai dari zaman nabi Adam AS samapai nabi Muhammad AS.

Sedang indonesia dalam pembinaan hukumnya adalah sejak zaman diamna penduduk asli indonesia kono pra kemerdekaan diamna pembianaan hukum saat itu di tetapkan oleh raja-raja yang berkuasa dan juga kepala adat. Setelah kemerdekaan dominasi hukum di indonesia dari mengadopsi hukum belanda Baik STABLAT ataupun BW. Pengaruh hukum belanda terhadap perkembangan hukum diindonesia sangat dominan walau tak sedikit yang bertentangan dengan hukum adat setempat, hal ini karena belum mampunya indonesia untuk mengimbangi madzab huku terbesar civil law sistem itu.

Sedang menurut fakar ahli hukum menyebutkan sebagaiman berikut ini:

1. VAN KAN., Hukum ialah keseluruhan peraturan hidup yang bersifat memaksa untuk melindungi kepentingan manusai di dalam masyarakat. Peraturan dalam menjalankan kehidupan diperlukan untuk melindungi kepentingan dengan tertib.13

2. UTRECHT., Hukum adalah himpunan peraturan (baik berupa perintah maupun larangan) yang mengatur tata tertib dalam suatu masyarakat dan seharusnya ditaati oleh anggota masyarakat yang bersangkutan. Oleh karena itu, pelanggaran petunjuk hidup tersebut dapat menimbulkan tindakan dari pihak pemerintah.14

3. WIRYONO KUSUMO.,Hukum adalah keseluruhan peraturan baik yang tertulis maupun tidak tertulis yang mengatur tata tertib dalam masyarakat dan terhadap pelanggarnya umumnya dikenakan sanksi. Sedangkan tujuan dari hukum adalah untuk mengadakan keselamatan, kebahagiaan, danketertiban dalam masyarakat. 15

Dari beberapa definisi diatas dapat disimpulkan bahwa hukum adalah perturaan yang didalamnya terdapat norma dan berfungsi untuk melindungi hak manusia atau bukan manusi baik tertulis atau tidak, yang berisikan perintah atau larangan atas suatu perbutan yang menjadi pedoman masyarakat dimana hukum itu ada.

Fungsi hukum menurut Franz Magnis Suseno, adalah untuk mengatasi konflik kepentingan. Dengan adanya hukum, konflik itu tidak lagi dipecahkan menurut siapa yang paling kuat, melainkan berdasarkan aturan yang berorientasi pada kepentingan-

kepentingan dan nilai-nilai objektif dengan tidak membedakan antara yang kuat dan yang lemah, dan orientasi itu disebut keadilan. 16

Dalam pandangan Achmad Ali, bahwa fungsi hukum itu dapat dibedakan ke dalam:[4]

a. Fungsi hukum sebagai“a tool of social control".

b. fungsi hukum sebagai "a tool of social engineering".

c. fungsi hukum sebagai simbol,

d. fungsi hukum sebagai "a political instrument".

e. fungsi hukum sebagai integrator

Sedang sifat hukum sebagaimana kansil dalam bukunya ilmu hukum, hukum mepunyai sifat mengatur dan memaksa ia merupakan pengaturan-pengaturan hidup

12 Lampiran UU No. 20 Tahun 2003 Tentang SISDIKNAS

13Kansil, Pengantar Ilmu Hukum Dan Tata Hukum Indonesia. Balai Pustaka, Jakarta: 2002, h. 53

14 Kansil, Pengantar Ilmu Hukum Dan Tata Hukum Indonesia

15 Kansil, Pengantar Ilmu Hukum Dan Tata Hukum Indonesia

16 Siswoyo, Dwi, dkk.. Ilmu Pendidikan, 2007, H. 31 
kemasyarakatan yang dapat memaksa orang supaya mentaati tata tertib dalam masyarakat serta memberikan sangsi yang tegas (berupa hukuman) terhadap siapa yang tidak mau mentaatinya. 17

Secara khusus, pendidikan adalah usaha sadar yang dilakukan oleh keluarga, masyarakat, dan pemerintah, melalui kegiatan bimbingan, pengajaran, dan/atau latihan, yang berlangsung di dalam dan luar sekolah sepanjang hayat, untuk mempersiapkan peserta didik agar dapat memainkan peranan dalam berbagai lingkungan hidup secara tepat di masa yang akan datang (Mudyaharjo, 2008: 3, 11). Menurut Undang-Undang RI Nomor 2 Tahun 1989 tentang Pendidikan Nasional pasal 1 : "Pendidikan adalah usaha sadar dan terencana untuk mewujudkan suasana belajar dan proses pembelajaran agar peserta didik secara aktif mengembangkan potensi dirinya untuk memiliki kekuatan spiritual keagamaan, pengendalian diri, kepribadian, kecerdasan, akhlak mulia, serta keterampilan yang diperlukan dirinya, masyarakat, bangsa dan negara".18

Pendidikan sebagai usaha sadar yang selalu bertolak dari sejumlah landasan serta pengindahan sejumlah asas-asas tertentu. Landasan dan asas tersebut sangat penting, karena pendidikan merupakan pilar utama terhadap perkembangan manusia dan masyarakat bangsa tertentu. Secara umum, pendidikan merupakan segala pengalaman belajar yang berlangsung dalam segala lingkungan dan sepanjang hidup.

Landasan yuridis atau hukum pendidikan dapat diartikan seperangkat konsep peraturan perundang-undangan yang berlaku yang menjadi titik tolak atau acuan (bersifat material, dan bersifat konseptual) dalam rangka praktek pendidikan dan studi pendidikan. Jadi, landasan hukum pendidikan adalah dasar atau fondasi perundang-undangan yang menjadi pijakan dan pegangan dalam pelaksanaan pendidikan di suatu negara.

Tiap-tiap negara memiliki peraturan perundang-undangan sendiri. Landasan yuridis pendidikan Indonesia juga mempunyai seperangkat peraturan perundang-undangan yang menjadi titik tolak sistem pendidikan di Indonesia, yang meliputi :

- Pembukaan UUD 1945

- UUD 1945 sebagai Landasan Yuridis Pendidikan Indonesia.

- Pancasila sebagai Landasan Idiil Sistem Pendidikan Indonesia.

- Ketetapan MPR sebagai Landasan Yuridis Pendidikan Nasional

- Undang-Undang dan Peraturan Pemerintah sebagai Landasan Yuridis Pendidikan Nasional

- Keputusan Presiden sebagai Landasan Yuridis Pelaksanaan Pendidikan Nasional

- Keputusan Menteri sebagai Landasan Yuridis Pelaksanaan Pendidikan Nasional

- Instruksi Menteri sebagai Landasan yuridis Pelaksanaan Pendidikan Nasional

Landasan hukum pendidikan merupakan seperangkat peraturan dan perundangundangan yang menjadi panduan pokok dalam pelaksanaan sistem pendidikan di Indonesia. Peraturan yang satu dan yang lain seharusnya saling melengkapi. Permasalahan yang saat ini terjadi adalah perundangan dan peraturan yang ada belum sepenuhnya terlaksana dengan baik.

Pada batang tubuh UUD 1945 Pasal 31 Ayat 1 berbunyi : “Tiap - tiap warga negara berhak mendapatkan pengajaran". Pada kenyataannya masih banyak warga negara baik dari kelompok masyarakat miskin, daerah tertinggal dan sebagainya yang belum mendapatkan pengajaran seperti yang dimaksud dalam Undang-Undang tersebut.

Pada UU No. 20 Tahun 2003 Tentang Sisdiknas Pasal 4 ayat 2 berbunyi : "Pendidikan diselenggarakan secara demokratis dan berkeadilan serta tidak diskriminatif dengan menjunjung tinggi hak asasi manusia, nilai keagamaan, nilai kultural, dan kemajemukan bangsa". Namun dalam kenyataanya sebagian penyelenggaraan pendidikan belum sesuai dengan peraturan tersebut. Penyelenggaraan pendidikan masih saja bersifat diskriminatif dan tidak menjunjung hak asasi manusia. Misalnya dalam penyelenggaraan pendidikan di RSBI dengan pelajarannya yang begitu padat siswa kehilangan hak-haknya untuk bermain, serta diskriminatif karena hanya siswa yang pandai dan mampu saja yang bisa menempuh pendidikan disana. 
Kita akan masih banyak menemukan beberapa undang-undang yang belum mencapai tujuannya, karena bangsa Indonesia merupakan bangsa yang majemuk, tentu tidak mudah mencapai semua tujuan dengan singkat dan cepat. Tercapainya tujuan pendidikan membutuhkan dukungan positif dari pendukung segala aspek masyarakat, penyelenggara pendidikan dan pemerintah. Maka penyelenggaraan pendidikan yang baik adalah sesuai dengan landasan-landasan pendidikan. Pelaksanaan pendidikan yang berlandaskan hukum akan menjadikan penyelenggaraan pendidikan terarah, teratur dan sesuai dengan akar kebudayaan nasional.19

Penddidikan hal yang paling penting dalam kehidupan manusia atau juga dalam kesejahteraanya. Manusia yang mempunyai beberapa unsure, unsure manusia yang berupa akal yang di dapat dari salah satu organ tubuh yakni otak dimana otak berfungsi untuk menyimpan memori dan juga naluri atau nafsu yang mendorong manusia untuk berbuat, mengetahui dan mempelajari setiap sesuatu yang ada didepannya akan mendorong manusia untuk selalu tahu, kedua unsure organ manusia itu juga harus di fungsikan dengan baik.

Pemungsian dua unsure itu sangat di tekankan oleh semua agama, islam contohnya. Dalam islam entah bebarapakali teguran untuk menggunakan otak agar difungsikan sebagaimana fungsinya. Hal ini jika melihat Al-qur'an begitu banyak anjuran untuk memungsikan otak dengan gaya bahsa Al-qur'an yang apik spertiAfala Taqilun, afala tadzakaru, afala tadzakarun. Ini membuktikan akan pentingnya otak dalam pemunsianya sebagai alat untuk menerima dan menyipan pengetahuan. Begitu pentingya pengetahuan sehingga menyebabkan begitu pentingnya pendidikan dalam mencari pengetahuan itu. Hal ini memgundang dirasa pentingnya kawalan untuk mengawal jalannya pendidikan agar berjalan dengan baik.

Pendidikan diindonesia diploklamirkan oleh Ki Ageng Dewantoro pada abad 20, akan tetapi bukan berarti pendidkan di Indonesia ada pada saat itu. Indonesia dan pendidikan sudah lama mengenal pendidikan. Sebagaimana statemen diatas bahwa pendidikan dan ilmu pengetahuan itu lahir sejak adanya manusia, sebagaiman di ceritakaan melalui asbabul wurud dalam kitab Tafsir Jalalein karaya jaludin As-syuyuti dan jalaludin Al-mahali, bahwa ketika Nabi Adam AS diturunkan Nabi Adam sedang belajar dengan jibril untuk mengenal benda-benda di bumi. Begitu juga Indonesia jika di tilik dari historisi pendidikan maka pendidikan ada sejak adanya penduduk di bumi Indonesia dimana para wali songo membuat surau untuk mengajarkan tentang agama islam. Dan pada kesempatan yang sangat mencolok yang dibentuk kelembagaan dan model pemblajaran pendidikan formal sejak di plokamirkan oleh Ki Ageng Dewantoro setelah kemerdekaan Indonesia.20 Sebagaimana cita-cita para pauding father Negara ini dalamUndang-Undang Dasar Negara Republik Indonesia tahun 1945 mengamanatkan Pemerintah Negara Indonesia yang melindungi segenap bangsa Indonesia dan seluruh tumpah darah Indonesia dan untuk memajukan kesejahteraan umum, mencerdaskan kehidupan bangsa, dan ikut melaksanakan ketertiban dunia yang berdasarkan kemerdekaan, perdamaian abadi dan keadilan sosial. Maka di bentuklah undang-undang yang mengatur tentang pelaksanaan pendidikan, pengadaan pendidikan dan juga propesi pendidik. Dan lahirlah Undang-Undang Republik Indonesia Nomor 20 Tahun 2003 tentang Sistem Pendidikan Nasional, dimana pada sebelumnya UU sitemtem pendidikan terdapat pada Undangundang Nomor 2 Tahun 1989 tentang Sistem Pendidikan Nasional, hal ini karena dirasa Sistem Pendidikan Nasional tidak memadai lagi dan perlu diganti serta perlu disempurnakan agar sesuai dengan amanat perubahan Undang-Undang Dasar Negara Republik Indonesia Tahun 1945.21

Adanya UU Tentang pendidikan menjukan begitu eratnya hubungan pendidikan dengan hukum. Dimana pelaksanaan, pengadaan pendidikan dan propesi pendidik menjadi terlindungi dengan adanya UU tentang pendidikan tersebut. Hal ini sebagaimana azaz dan fungsi hukum yang di dalamnya terdapata tool of social control, a tool of social 
engineering, sebagai symbol, a political instrument dan sebagai integrator. Dari fungsi hukum yang ada pada setiap hukum pada setiap benda dan subyek hukum maka hal itu juga terdapat pada hukum yang terakndung dalam pasal-pasal dalam UU tentang pendidikan.

a.Kompetensi profesional

b.Kompetensi personal

c.Kompetensi sosial

Untuk konteks Indonesia, dewasa ini telah dirumuskan syarat kompetensi yang harus dimiliki oleh seorang guru menurut UU No. 14 Tahun 2005 Tentang Guru dan Dosen. Pada pasal 10 undang-undang tersebut disebutkan bahwa kompetensi guru meliputi kompetensi pedagogik, kompetensi kepribadian, kompetensi sosial, dan kompetensi profesional yang diperoleh melalui pendidikan profesi. 22

Guru yang baik adalah guru yang bisa menguasai keempat kompetensi di atas. Dewasa ini banyak kebijakan yang ditempuh pemerintah dalam upaya mencari sosok guru yang baik dan memiliki kemampuan yang berkompoten. Untuk mencapai kompetensi yang diharapkan, maka kualitas guru harus dioptimalkan.

\section{Masalah Hukum Pendidikan di Indonesia}

Para pendidik dan masyarakat umum perlu bersikap dan bertindak positif mensukseskan tujuan pendidikan tersebut, antara lain dengan cara :

1. Memberikan dorongan kepada peserta didik dan warga belajar untuk belajar terus

2. Mengurangi beban kerja anak-anak manakala mereka harus membantu meringankan beban ekonomi orang tuanya

3. Membantu menyiapkan lingkungan belajar dan alat-alat belajar di rumah untuk merangsang kemauan belajar anak-anak

4. Membantu biaya pendidikan

5. Mengijinkan anak pindah sekolah, bila ternyata sekolah semula sudah tidak dapat menampung

6. Bila diperlukan, membantu menyiapkan gedung untuk lokasi belajar

7. Bersedia menjadi narasumber untuk keterampilan-keterampilan tertentu yang banyak dibutuhkan para pendidik dasar tingkat-tingkat akhir

8. Mengizinkan peserta didik dan warga belajar magang di perusahaan-perusahaan dan perdagangan-perdagangan

9. Responsif terhadap kegiatan-kegiatan sekolah, terutama yang dilaksanakan di masyarakat

10. Bersedia menjadi orang tua angkat atau orang tua asuh bagi anak-anak yang sudah tidak memiliki orang tua, atau orang tuanya tidak mampu membiayai anakanaknya.

\section{E. Tujuan Pendidikan}

Menurut UU Sisdiknas No. 20 tahun 2003, bab II pasal 3 pendidikan bertujuan untuk berkembangnya potensi peserta didik agar menjadi manusia yang beriman dan bertakwa kepada Tuhan Yang Maha Esa, berakhlak mulia, sehat, berilmu, cakap, kreatif, mandiri, dan menjadi warga negara yang demokratis, serta bertanggung jawab.

Tujuan pendidikan merupakan sesuatu yang ingin dicapai oleh kegiatan pendidikan. Adalah suatu yang logis bahwa pendidikan itu harus dimulai dengan tujuan, yang diasumsikan sebagai nilai. Tanpa dasar tujuan, maka dalam praktek pendidikan tidak ada artinya.

Ada bermacam-macam tujuan pendidikan menurut para ahli. MJ. Langeveld mengemukakan ada enam macam tujuan pendidikan, yaitu (1) tujuan umum, total atau akhir, (2) tujuan khusus, (3) tujuan tak lengkap, (4) tujuan sementara, (5) tujuan intermedier dan (6) tujuan insindental. 
Tujuan pendidikan di Indonesia bisa dibaca pada GBHN, berbagai peraturan pemerintah dan undang-undang pendidikan. Dalam GBHN 1993 dijelaskan bahwa kebijaksanaan pembangunan sektor pendidikan ditujukan untuk meningkatkan kualitas manusia Indonesia, yaitu manusia yang beriman dan bertakwa kepada Tuhan Yang Maha Esa, berbudi pekerti luhur, berkepribadian, mandiri, maju, tangguh, cerdas, keratif, terampil, beridsiplin, beretos kerja, profesional, bertanggung jawab, produktif, dan sehat jasmani-rohani. Indikator-indikator tujuan pendidikan di atas dapat dikelompokkan menjadi empat, yaitu:

1. Hubungan dengan Tuhan, ialah beriman dan bertakwa kepada Tuhan Yang Maha Esa.

2. Pembentukkan pribadi, mencakup berbudi pekerti luhur, berkepribadian, mandiri, maju, tangguh, cerdas, dan kreatif.

3. Bidang usaha, mencakup terampil, berdisiplin, beretos kerja, profesional, bertanggung jawab, dan produktif.

4. Kesehatan, yang mencakup kesehatan jasmani dan rohani.23

Tujuan pendidikan di Indonesia seperti telah diuraikan di atas adalah untuk membentuk manusia seutuhnya, dalam arti berkembangnya potensi-potensi individu secara harmonis, berimbang dan terintegrasi. Bila hal ini dapat dilaksanakan dengan baik, sudah tentu harapan-harapan para ahli dapat tercapai. Tujuan pendidikan ini pun mengembangkan potensi-potensi individu seperti apa adanya. Meskipun ada kebijakan tertentu yang agak berbeda arah dengan tujuan ini dengan maksud-maksud tertentu, diharapkan kebijakan itu tidak terlalu dipertahankan. Dengan demikian secara konsep atau dokumen tujuan pendidikan Indonesia tidak berbeda secara berarti dengan tujuan-tujuan pendidikan yang diinginkan oleh para ahli pendidikan di dunia.24

Degan demikian untuk mencapai tujuan pendidikan, dibutuhkan tenaga pendidik yang memiliki kompetensi. Berikut akan diuraikan kompetensi dan dimensi-dimensi kompetensi guru.

Kompetensi berarti suatu hal yang menggambarkan kualifikasi atau kemampuan seseorang, baik yang kualitatif maupun yang kuantitatif. McAhsan (Mulyasa, 2003:38) mengemukakan bahwa kompetensi: "is a knowledge, skills, and abilities or capabilities that a person achieves, wich become part office or her being to the extent he or she can satisfactorily perform particular cognitive, affective, and psychomotor behaviours". Dalam hal ini, kompetensi diartikan sebagai pengetahuan, keterampilan dan kemampuan yang dikuasai oleh seseorang yang telah menjadi bagian dari dirinya, sehingga ia dapat melakukan perilaku-perilaku kognitif, afektif dan psikomotorik dengan sebaik-baiknya. Sejalan dengan itu, Finch dan Crunkilton (Mulyasa, 2003: 38) mengartikan kompetensi sebagai penguasaan terhadap suatu tugas, keterampilan, sikap, dan apresiasi yang diperlukan untuk menunjang keberhasilan.

Kompetensi tidak hanya mengandung pengetahuan, keterampilan dan sikap, namun yang penting adalah penerapan dari pengetahuan, keterampilan dan sikap yang diperlukan tersebut dalam pekerjaan. Kompetensi adalah karakteristik dasar seseorang yang berkaitan dengan kinerja berkriteria efektif dan atau unggul dalam suatu pekerjaan dan situasi tertentu. Sifat intelegen harus ditunjukkan sebagai kemahiran, ketetapan, dan keberhasilan bertindak. Sifat tanggung jawab harus ditunjukkan sebagai kebenaran tindakan baik dipandang dari sudut ilmu pengetahuan, teknologi maupun etika.

Depdiknas (2004: 7) merumuskan definisi kompetensi sebagai pengetahuan, keterampilan dan nilai-nilai dasar yang direfleksikan dalam kebiasaan berfikir dan bertindak. Guru yang kompeten dan profesional adalah guru yang piawai dalam melaksanakan profesinya.

Dengan demikian Kompetensi guru dapat dapat diartikan sebagai penguasaan terhadap pengetahuan, keterampilan, nilai dan sikap yang direfleksikan dalam kebiasaan berpikir dan bertindak dalam menjalankan profesi sebagai guru.

\section{a. Kompetensi Pedagogik}


Dalam UU No. 14 tahun 2005 tentang guru dan dosen dikemukakan kompetensi pedagogic adalah "kemampuan mengelola pembelajaran peserta didik". Depdiknas (2004: 9) menyebut kompetensi ini dengan "kompetensi pengelolaan pembelajaran". Kompetensi ini dapat dilihat dari kemampuan merencanakan program belajar mengajar, kemampuan melaksanakan interaksi atau mengelola proses belajar mengajar, dan kemampuan melakukan penilaian. Kompetensi menyusun rencana pembelajaran mencakup kemampuan: (1) merencanakan pengorganisasian bahan-bahan pengajaran, (2) merencanakan pengelolaan kegiatan belajar mengajar, (3) merencanakan pengelolaan kelas, (4) merencanakan penggunaan media dan sumber pengajaran, dan (5) merencanakan penilaian prestasi siswa untuk kepentingan pengajaran. Menurut Siswoyo (2006) kompetensi Pedagogik bukanlah kompetensi yang hanya bersifat teknis belaka, yaitu "kompetensi mengelola peserta didik.." (yang dirumuskan dalam PP RI No. 19 tahun 2005), karena "pedagogy" or "paedagogy" adalah "the art and science of teaching and educating”. 25

Depdiknas (2004: 9) mengemukakan kompetensi penyusunan rencana pembelajaran meliputi; (1) mampu mendeskripsikan tujuan, (2) mampu memilih materi, (3) mampu mengorganisir materi, (4) mampu menentukan matode/strategi pembelajaran, (5) mampu menentukan sumber belajar/media/alat peraga pembelajaran, (6) mampu menyusun perangkat penilaian, (7) mampu menentukan teknik penilaian, dan (8) mampu mengalokasikan waktu. Berdasarkan uraian di atas, merencanakan program belajar mengajar merupakan proyeksi guru mengenai kegiatan yang harus dilakukan siswa selama pembelajaran berlangsung, yang mencakup : merumuskan tujuan, menguraikan deskripsi satuan bahasan, merancang kegiatan belajar mengajar, memilih berbagai media dan sumber belajar, dan merencanakan penilaian penguasaan tujuan. Kompetensi pedagogic ini mencakup pemahaman dan pengembangan potensi peserta didik, perencanan dan pelaksanaan pembelajaran, serta system evaluasi pembelajaran, juga harus menguasai "ilmu pendidikan". Kompetensi ini diukur dengan performance test atau episodes terstruktur dalam praktek pengalaman lapangan (PPL), dan tase based test yang dilakukan secara tertulis.

\section{b. Kompetensi Kepribadian}

Guru sebagai tenaga pendidik yang tugas utamanya mengajar, memiliki karakteristik kepribadian yang sangat berpengaruh terhadap keberhasilan pengembangan sumber daya manusia. Kepribadian yang mantap dari sosok seorang guru akan memberikan teladan yang baik terhadap anak didik maupun masyarakatnya, sehingga guru akan tampil sebagai sosok yang patut "digugu" (ditaati nasehat/ucapan/perintahnya) dan "ditiru" (dicontoh sikap dan perilakunya). Kepribadian guru merupakan faktor terpenting bagi keberhasilan belajar anak didik. Kepribadian itulah yang akan menetukan apakah ia menjadi pendidik dan pembina yang baik bagi anak didiknya, ataukah akan menjadi perusak atau penghancur bagi masa depan anak didiknya terutama bagi anak didik yang masih kecil (tingkat dasar) dan mereka yang sedang mengalami kegoncangan jiwa (tingkat menengah).

Karakteristik kepribadian yang berkaitan dengan keberhasilan guru dalam menggeluti profesinya adalah meliputi fleksibilitas kognitif dan keterbukaan psikologis. Fleksibilitas kognitif atau keluwesan ranah cipta merupakan kemampuan berpikir yang diikuti dengan tindakan secara simultan dan memadai dalam situasi tertentu. Guru yang fleksibel pada umumnya ditandai dengan adanya keterbukaan berpikir dan beradaptasi. Selain itu, ia memiliki resistensi atau daya tahan terhadap ketertutupan ranah cipta yang premature dalam pengamatan dan pengenalan. Dalam UU guru dan dosen dikemukakan kompetensi kepribadian adalah "kemampuan kepribadian yang mantap, berakhlak mulia, arif dan berwibawa serta menjadi teladan peserta didik".26

\section{Upaya Mengoptimalkan Kualitas Guru dengan Mengoptimalkan Kompetensi Pedagogik dan Kompetensi Kepribadian}


a. Melaksanakan proses belajar mengajar

Melaksanakan proses belajar mengajar merupakan tahap pelaksanaan program yang telah disusun. Dalam kegiatan ini kemampuan yang dituntut adalah kreatif guru menciptakan dan menumbuhkan kegiatan siswa belajar sesuai dengan rencana yang telah disusun. Guru harus dapat mengambil keputusan atas dasar penilaian yang tepat, apakah kegiatan belajar mengajr dicukupkan, apakah metodenya diubah, apakah kegiatan yang lalu perlu diulang, manakala siswa belum dapat mencapai tujuan-tujuan pembelajaran. Pada tahap ini di samping penentuan teori belajar mengajar, pengetahuan tentang siswa, diperlukan pula kemahiran dan keterampilan teknik belajar, misalnya: prinsip-prinsip belajar, penggunaan alat bantu pengajar, penggunaan metode belajar, dan keterampilan menilai hasil belajar siswa.

b. Melaksanakan penilaian proses belajar mengajar

Penilaian proses belajar mengajar dilaksanakan untuk mengetahui keberhasilan perencanaan kegiatan belajar mengajar yang telah disusun dan dilaksnakan. Penelitian diarikan sebagai proses yang menentukan betapa baik organisasi program atau kegiatan yang dilaksanakan utnuk mencapai maksud-maksud yang telah ditetapkan. Evaluasi merupakan bagian yang tidak terpisahkan dari setiap upaya manusia, evaluasi yang baik akan menyebarkan pemahaman dan perbaikan pendidikan sedangkan evaluasi yang salah akan merugikan pendidikan.

Tujuan utama melaksanakan evaluasi dalam proses belajar mengajar adalah untuk mendapatkan informasi yang akurat mengenai tingkat pencapaian tujuan instruksional oleh siswa, sehingga tindak lanjut hasil belajar akan dapat diupayakan dan dilaksanakan. Dengan demikian, melaksanakan penelitian proses belajar mengajar merupakan bagian tugas guru yang harus dilaksanakan setelah kegiatan pembelajaran berlangsung dengan tujuan untuk mengetahui tingkat keberhasilan siswa mencapai tujuan pembelajaran, sehingga dapat diupayakan tindak lanjut hasil belajar siswa.27

\section{Kesimpulan}

Hubungan antara pendidikan dan hukum bisa dikatakan sangat erat sekali. Pemerhati pendidikan pasti akan bercita-cita bagaimana pendidikan dapat berjalan dengan baik dan untuk mendukung eksitensi pendidikan maka di buatlah sebbuah UU yang mengatur tentang hukum pendidikan itu agar menjadi sebua norma dan juga patokan system pendidikan. Hukum sebagai pedoman baik berupa perintah ataupun larangan, baik tertulis ataupun tidak mau tidak mau harus di patuhi. Karena dalam hukum itru sendiri terdapat asaz hukum yakni memberikan sebuah hukuman atau hak setiap orang atau subyek hukum yang berusa menyengaja melanggar hukum yang ditetapkan. Didalam pendidikan pun akan tamapak membaik jika ada hukum yang tertulis dalam mengatur system pendidikan. Dan hukumpun juga membutuhkan suatu pendidikan dalam perkembangannya.

Kegiatan pendidikan merupakan kegiatan antar manusia, oleh manusia dan untuk manusia. Oleh karena itu pendidikan tidak pernah lepas dari unsur manusia. Para ahli pendidikan pada umumnya sepakat bahwa pendidikan itu diberikan atau diselenggarakan dalam rangka mengembangkan seluruh potensi manusia ke arah yang positif.

Pendidikan pada dasarnya adalah proses kumunikasi yang di dalamnya mengandung transformasi pengetahuan, nilai-nilai dan keterampilan-keterampilan, di dalam dan di luar sekolah yang berlangsung sepanjang hayat (life long process), dari generasi ke generasi. 


\section{Referensi}

Lampiran UU No. 20 Tahun 2003 Tentang SISDIKNAS

Kansil, pengantar Ilmu hukum dan tata hukum Indonesia. Balai Pustaka. Jakarta. http://id.shvoong.com/law-and-politics/law/2093155-fungsi-hukum/\#ixzz1g6vFvW2g Lampiran UU No. 20 Tahun 2003 Tentang SISDIKNAS

Mkalah Hazairin. Kuliah Umum I 1954/1955

Kansil, pengantar Ilmu hukum dan tata hukum Indonesia. Balai Pustaka. Jakarta.

Siswoyo, Dwi, dkk. 2007. Ilmu Pendidikan. UNY Press. Yogyakarta

UU Sikdiknas. 2006. Pustaka Pelajar. Yogyakarta

UU Sisdiknas No. 20 Tahun 2003.

UU Guru dan Dosen. 2005. Pustaka Pelajar: Yogyakarta

Peraturan Menteri Nomor 18 Tahun 2007, tentang Sertifikasi bagi Guru dalam Jabatan Peraturan Menteri Nomor 11 Tahun 2005, tentang Buku Teks Pelajaran

Pidarta, Made. 2000. Landasan Kependidikan. Rineka Cipta: Jakarta

Peraturan Menteri No. 16/18. www.google.com, akses 10 Januari 2009 